\title{
SENP1 Gene
}

National Cancer Institute

\section{Source}

National Cancer Institute. SENP1 Gene. NCI Thesaurus. Code C98061.

This gene is involved in both apoptosis regulation and protein desumoylation. 